\title{
Bacon, Friedman, Themerson or How to Translate Anything to Anything
}

\section{[...] and now the thought has changed into colour and the colour has changed into sound and the sound has changed into silence.}

Stefan Themerson, “Hobson's Island” (1988: 196)

In the 1570s Francis Bacon developed a method for concealing a message inside a different text or - as we will see in a moment-inside an image or a musical score. His cipher is a binary code (a little bit like Morse Code or the ASCII Code used in our computers) in which actual letters of the alphabet have been replaced by combinations of only two characters: " $\mathrm{A}$ " and " $\mathrm{B}$ ", always in groups of five. Here is the whole system:

$$
\begin{aligned}
& \mathrm{a}=\mathrm{AAAAA}, \mathrm{b}=\mathrm{AAAAB}, \mathrm{c}=\mathrm{AAABA}, \mathrm{d}=\mathrm{AAABB}, \\
& \mathrm{e}=\mathrm{AABAA}, \mathrm{f}=\mathrm{AABAB}, \mathrm{g}=\mathrm{AABBA}, \mathrm{h}=\mathrm{AABBB}, \\
& \mathrm{i} / \mathrm{j}=\mathrm{ABAAA}, \mathrm{k}=\mathrm{ABAAB}, \mathrm{l}=\mathrm{ABABA}, \mathrm{m}=\mathrm{ABABB}, \\
& \mathrm{n}=\mathrm{ABBAA}, \mathrm{o}=\mathrm{ABBAB}, \mathrm{p}=\mathrm{ABBBA}, \mathrm{q}=\mathrm{ABBBB}, \\
& \mathrm{r}=\mathrm{BAAAA}, \mathrm{s}=\mathrm{BAAAB}, \mathrm{t}=\mathrm{BAABA}, \mathrm{u} / \mathrm{v}=\mathrm{BAABB}, \\
& \mathrm{w}=\mathrm{BABAA}, \mathrm{x}=\mathrm{BABAB}, \mathrm{y}=\mathrm{BABBA}, \mathrm{z}=\mathrm{BABBB} .
\end{aligned}
$$

What makes it different from other ciphers and methods of steganography ${ }^{1}$ is that one can substitute these two characters with any other two signs: squares and triangles, minuses and pluses, whatever. In a printed text - any text of a right length - the letters " $\mathrm{A}$ " and " $\mathrm{B}$ " can be represented by two different typefaces, for example: regular and italic How it works can be best shown in an example given by Bacon himself, warning a secret agent to flee:

Do not go till I come = aabab ababa babba = fly (qtd. by Sherman 2010: 11).

\footnotetext{
${ }^{1}$ Ancient art of concealing a text or image in another text or image.
} 
While discussing ciphers in the first edition of his philosophical book The Advancements of Learning, published in 1605, Bacon stated that actually anything can signify anything ("omnia per omnia") by virtue of, as he called it, "infoulding" it (Bacon, Blackbourne 1730: 497).

Almost three centuries after Bacon published his fully developed cipher in the second Latin edition of his Advancements (1623), William F. Friedman, a young genetics scientist turned cryptographer, used the principle of the Baconian cipher to arrange seventy-one officers whom he had taught the art of cryptology in Aurora, Illinois, in the winter of 1918, in such a way that to the well-trained eye they formed a ciphered message: "Knowledge is power". Actually the last word of Bacon's credo was incomplete, since there were not enough soldiers for the final " $r$ ", as can be seen in a photograph of the group that Friedman kept in his office for most of his life. The two letters of the cipher were substituted with men looking either forward or sideways.

It is said that William F. Friedman, a Russian-born American expert on cryptography, developed an interest in ciphers after reading Edgar Allan Poe's story "The Golden Bug". He studied plant biology at Cornell University where he was recruited by George Fabyan, a shady businessman and the founder of Riverbank Laboratories, an engineering and acoustical laboratory whose secondary major goal was deciphering Shakespeare's plays to prove that they had been written by Bacon. Originally employed in the Department of Genetics of RL, Friedman soon got involved in the above mentioned Baconian project supervised by Elizabeth Wells Gallup, a former school principal, who sincerely believed that Bacon had concealed secret messages in works attributed to Shakespeare. Gallup's assistant at that time was Elizabeth Smith who later became Friedman's wife. Together in the 1950s the Friedmans delivered the final blow to the authorship controversy by publishing The Shakespearean Ciphers Examined (Friedman, Friedman 1957) which, as Laura Massey (2011) has put it, "conclusively demolished the theory that any encoded messages are present in early editions of Shakespeare".

During his tenure at Riverbank Laboratories, Friedman, whose main claim to fame was analyzing how the Japanese cipher machine known as PURPLE functioned at the beginning of WW II, devised a number of brilliant examples of possible uses of the Baconian cipher. One of them is a detailed botanical drawing of "the most interesting and peculiar plant". Its roots conceal Bacon's own name and the leaves and flower - other names of writers he secretly adopted: Marlowe, Greene, Peele, Spenser, Burton, and Shakespeare at the top. Another example takes the form of sheet music for a popular $19^{\text {th }}$ century song "My Old Kentucky Home, Good Night". This 
can be decrypted as: "Enemy advancing right / We march at daybreak". At the bottom Friedman added an explanation: "An example of making anything signify anything" (qtd. after Sherman 2010: 11).

Soon the enemy - as William S. Sherman (2010: 11) has pointed out - advanced close enough to engage Friedman as an expert cryptographer in military service for the rest of his life.

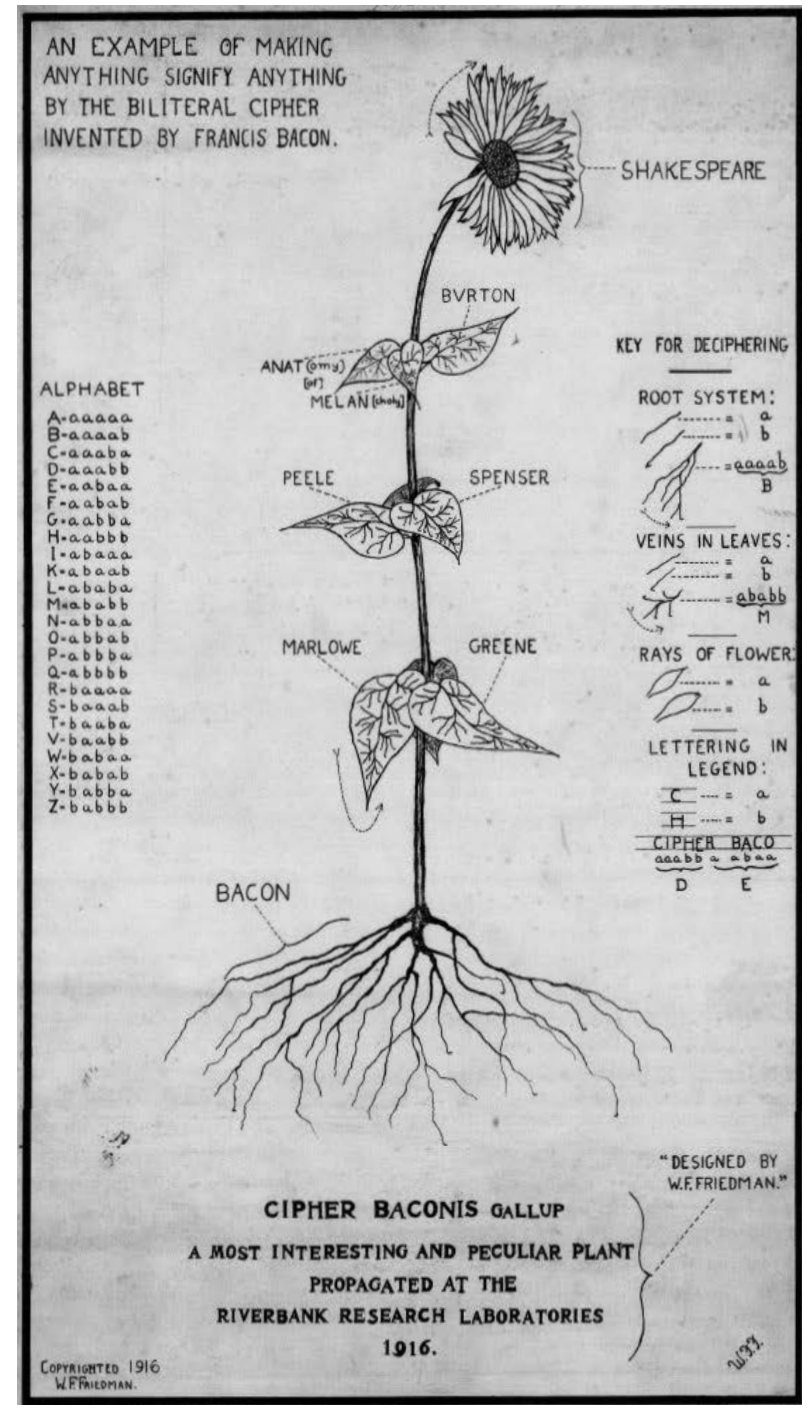

Figure 1. William F. Friedkin, drawing concealing names of Bacon, Marlowe, Greene, Peele, Spenser, Burton, and Shakespeare. Manuscript in the collection of New York Public Library 
Putting the Baconian cipher aside, it is worth noticing that the idea of not really hiding but certainly uncovering secret and often unexpected messages in pre-existing texts, images, musical scores, etc. proved a fruitful one in the arts and literature of the $20^{\text {th }}$ century. One of the greatest practitioners of this kind of "discoveries" was Stefan Themerson (1910-1988), a Polish-born writer, publisher and avant-garde filmmaker who lived in London from 1942 to the end of his life. Being stuck for several months at the beginning of WW II in a hostel of the Polish Red Cross, the Hôtel de la Poste in Voiron, France, he developed a concept of Semantic Poetry (SP), first presented in 1949 in his short novel Bayamus and later developed in the book of essays On Semantic Poetry (1975). According to the writer, the idea was to "strip words of their associations, to cut their links with the past".

This rebellion was anti-romantic and anti-ecstatic. It was directed both against political rhetoricians and against Joycean avant-coureurs. Against associational thickets of Eliot and the verboidal surrealisms of History. I wanted to disinfect words, scrub them right to the very bone of their dictionary definitions. That was how - somewhat ferociously and sardonically - I invented Semantic Poetry. It was meant to be funny. Both serious and funny. It became the subject of my novel Bayamus. (Wadley, "Reading Stephan Themerson")

Technically speaking, Semantic Poetry is made by replacing the words of a text, usually a poem or lyrics, by their dictionary definitions. Let us see how it works in the case of Winifred Galbraith's translation of a Chinese poem whose first lines go like this:

The wine among the flowers,

O lonely me!

In Themerson's translation to Semantic Poetry the same two lines become:

The fermented

grape-

juce

among the reproductive

parts

of

seed plants

(Themerson 1965: 66, 69)

The SP version of a well-known Russian ballad Haida Troika looks even more spectacular. Here is just the beginning. 


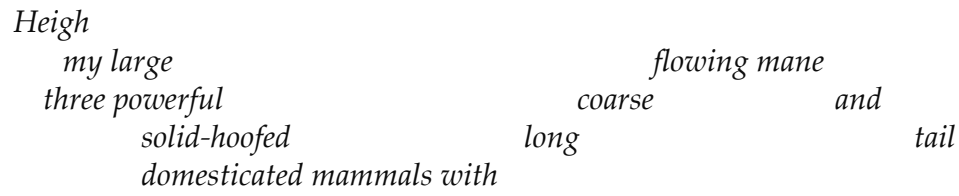

The narrator of Bayamus, an alter ego of the writer, explains that in 1916 in Russia, when he was six years old, he was taken in a troika for a ride. The translation which the above fragment is part of is "a better account of that wonder which enchanted [...] the eyes of a child, than the original ballad" (Themerson 1965: 73).

The unorthodox look of this SP translation stems from Themerson's idea that a poem can be read horizontally or vertically:

You may read horizontally the melody of [a] poem, but you may also take each of its words and score it vertically for your whole intellectual orchestra, you may give each of them the flesh of exact definition; instead of allowing them to evoke the clichés stored in your mind, you may try to find the true reality to which every word points, and that is what I call Semantic Poetry. (Themerson 1965: 66)

These examples show that although Semantic Poetry is regulated by a set of rules, it also leaves a lot of freedom for those who practice it. Nevertheless it uses an existing text as a sort of a score, or script if you will, for a totally new creation. Themerson exercised a similar approach to other media than poetry. In 1932 he and his wife Franciszka completed a film titled "Europa", considered by critics the most important work in the history of Polish avant-garde cinema. The film was based on a Futurist poem of the same title by Anatol Stern. The filmmakers decided to take words and phrases of the poem literary rather than looking for visual equivalents of verbal metaphors. So when the poet talks about "the liberated heart of man" the Themersons show "a beating heart - white on black", etc. The result was a string of images that were certainly derived from the poem but lived their own independent filmic life.

In their last film "The Eye and the Ear", completed in 1945, the Themersons created four visualizations for Karol Szymanowski (music) and Julian Tuwim's (lyrics) songs called "Słopiewnie". Arguably, the most interesting part of the film is the third one for which they set a very strict set of rules governing abstract shapes and their movements on screen. This is how it was done in Themerson's own words:

Rowan Towers. Each instrument of the orchestra represented by a simple geometrical form which changes its shape up and down according to the pitch of the note. Shapes representing different instruments were superimposed by multi-exposure, frame by frame. Crescendo, diminuendo, staccato, pizzicato, all had their visual counterpart. 
The vocal part was in 'unison' with a horizontal line in which a 'wrinkle', whose position depended on the pitch of the corresponding note, spread symmetrically to left and right. (Themerson 1983: 75-6)

This is another fine example of Themersonian interdisciplinary "translations". Once again we are dealing here with a preexisting piece that has been used as a "score" for something else. Of course "The Eye and the Ear" was not the first attempt in the history of cinema in creating an optical equivalent of music - one can recall films by Oskar Fischinger made in the 1920s and 1930s for instance - but none of these earlier works applied such precise rules and calculations in order to visually represent every component of the original music.

Another Themerson concept combining sounds with shapes is AVOTON (Audio-Visual One-To-One Normalizer). It is not quite clear when it was conceived but certainly before 1951. The goal of AVOTON was to create "a few simple rules, a simple arbitrary convention" for the audile representation of selected shapes, including symbols and letters. Themerson wrote that:

The results would be satisfactory if:

1. a blind person, listening to a series of notes, will recognize the corresponding shape and movement; $[\ldots]$

2. seeing a spatial structure on the screen would help people to grasp the corresponding temporal structure in the music.

If that were so, and the correlation had reprinted been learnt and assimilated, it would become possible:

1. to draw pictorial compositions by composing a new kind of music;

2. to compose a new kind of music by drawing moving-pictures.

(Themerson)

The following chart explains the basic principles of AVOTON:

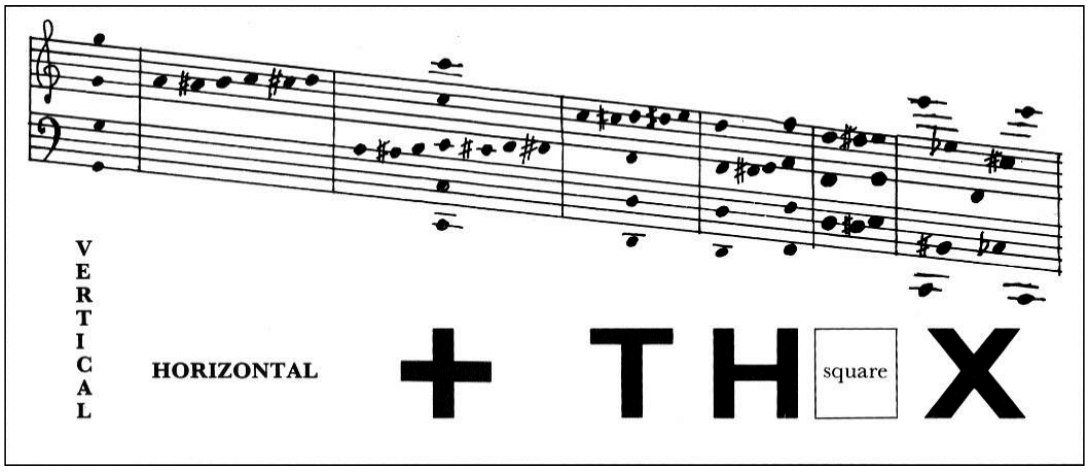

Figure 2. Basic principles of AVOTON (Themerson) 
Themerson also suggested that it would be useful to rebuild the standard keyboard, so it contained seven rows: "13 $(12+1)$ semitones in each row, the highest octave at the top, the lowest at the bottom" (Themerson 1983: 65). Such a keyboard could be connected to a "'Lightboard': a screen made of 7 horizontal rows of points of light, $13(12+1)$ in each row". Striking a key on a keyboard would light a corresponding point on the screen (Themerson 1983).

Since AVOTON many other artists and scientists have continued to try similar direct "translations" of different data into the realm of sound. One of the most interesting explorations of this kind is offered by Music Algorithms, a software created in 2004 by Jonathan N. Middleton, a professor of composition at the Eastern Washington University, that converts any string of numbers into music. ${ }^{2}$ The program, which is free to use on the internet, does not simply "translate" given digits into sounds, it gives also controls that allow the user to choose the pitch, tempo, and other aspects of the final "composition". One of the most devoted and inspired practitioners of composition using the software is Forest M. Mims III, a writer of popular books on science, who, among his other activities, has made music out of one-year-long measurements of solar ultraviolet radiation (Forest M. Mims III, The Sound) or numbers showing the growth of tree rings in a period of thirty-three years (1977-2010) (Forest M. Mims III, Converting Tree Rings).

But even before computers, artists investigated similar ideas. In Memoriam to Adriano Olivetti (1962), a classical piece of this type conceived by George Maciunas, the leader of Fluxus, used adding machine tapes as scores for a performance:

Each performer chooses any number from a used adding machine paper roll.

Performer performs whenever his number appears in a row. Each row indicates the beat of metronome. Possible actions to perform on each appearance of the number:

1) bowler hats lifted or lowered.

2) mouth, lip, tongue sounds.

3) opening, closing umbrellas etc.

(Home 1988: 53).

At least one artist proved that it is possible to reverse the idea of making art out of a string of randomly picked up numbers and make a string of numbers out of one's life. In 1965, Roman Opałka, a wellknown Polish graphic artist, started to exclusively paint numbers from one to infinity. He covered $196 \times 135 \mathrm{~cm}$ canvases from the top left-hand corner to the bottom right-hand one with tiny consecutive numbers. $\mathrm{He}$

${ }^{2}$ http://musicalgorithms.ewu.edu/. 
continued this task, working for twelve hours a day, until he died in 2011. The final number he managed to record was 5607249. These digits encode more than $3 / 5$ of his life. They encompass the aging, changes of mood, and moments of weakness of the artist. And since there is no way to decode them, they will always possess this kind of ambiguity and mystery that makes the great art.

So far I have tried to show that there are many ways of ciphering, translating or transforming messages, sounds, or shapes into something else. It is now time to put some order to this catalogue. A regular cipher translates a message to a system of signs that can be converted back to the message. In this respect, it is similar to music. In most cases one can go back from the audio to the original score. In literary translation one cannot retrieve the original text from its foreign language interpretation but at least can get a communique which is more or less close to the original. The Baconian cipher is different: having only the message, there is no way to go back to its carrier. In other words, there is a message that contains another ciphered message. The first one serves a disposable container. You can retrieve the latter but not the actual container once it is disposed of. Most of the artworks and actions described above are of a yet another kind. At the beginning there is a readymade artifact. Then there is a code, an algorithm that transforms it into something else. The final product is irreversible. It is a totally new entity. In the process of "translating", it gains new qualities that add a totally new value to the object, or whatever it is, that has been used as a matrix, a starting point for the operation. This value cannot be measured. It does not belong to the world of science. It does not communicate anything. Maybe this is exactly the territory where art occurs.

\section{References}

Bacon, Francis, John Blackbourne (1730). Francisci Baconi Baronis de Verulamio [...] Opera omnia quatuor voluminibus comprehensa: hactenus edita, ad autographorum maxime fidem emendantur, nonnulla etiam, ex mss. codicibus deprompta, nunc primum prodeunt [...]. Londini: Impensis R. Gosling, quoted after a reprinted version by Google Books: https://play.google.com/store/books/details?id=e 2JUAAAAYAAJ\&rdid=book-e2JUAAAAYAAJ\&rdot=1 [accessed June 5, 2020].

Forest M. Mims III. Converting Tree Rings into Music. https://www.youtube.com/ watch? $v=12 g 3 \operatorname{scrcg} 20$ [accessed June 5, 2020]. 
Forest M. Mims III. The Sound of the Sun's Ultraviolet Rays During One Year (2011). https://www.youtube.com/watch?v=VsRCrh6XWog [accessed June 5, 2020].

Friedman, William F., and Elizabeth S. Friedman (1957). The Shakespearean Ciphers Examined: An Analysis of Cryptographic Systems Used as Evidence that Some Author Other Than William Shakespeare Wrote the Plays Commonly Attributed to Him. Cambridge: Cambridge University Press.

Home, Stewart (1988). The Assault on Culture: Utopian Currents from Lettrism to Class War. London: Aporia Press and Unpopular Books. http://www. stewarthomesociety.org/ass/fluxone.htm [accessed June 5, 2020].

Massey, Laura (2011). Knowledge is Power: Shakespeare, Bacon, E Modern Cryptography. www.peterharrington.blog [accessed June 5, 2020].

Sherman, William H. (2010/11). "How to Make Anything Signify Anything". Cabinet 40 (Winter). http://www.cabinetmagazine.org/issues/40/sherman. php [accessed June 5, 2020].

Themerson, Stefan (1965). Bayamus and the Theater of Semantic Poetry. London: Gaberbocchus.

Themerson, Stefan (1983). The Urge to Create Visions. Amsterdam: Gaberbocchus + De Harmonie. Earlier the script was published in: Film as Film: Formal Experiment in film, 1910-1975. London: Hayward Gallery, 1979.

Themerson, Stefan (1988). Hobson's Island. London-Boston: Faber and Faber.

Wadley, Nicolas. "Reading Stefan Themerson". Context N¹6. http://www. dalkeyarchive.com/reading-stefan-themerson/ [accessed June 5, 2020]. 